His work led to more basic studies of the mechanisms of respiration in new-born animals, pursued with Dr. June Hill at St. Mary's and with Dr. G. S. Dawes and his colleagues at the Nuffield Institute for Medical Research at Oxford. Cross spent last year in Dr. Julius Comroe's laboratory at the University of California Medical Center and developed a method for inflating the infant's lungs which led to the dis. covery of surprising reflex mechanisms and may have opened an entirely new field. His many physiological and pædiatrical friends look forward to further important contributions from the London Hospital Medical College.

\section{Statistics at University College, London :}

Prof. E. S. Pearson, C.B.E.

Ar the end of the current session Prof. Egon Sharpe Pearson retires from University College, London, and for the first time in seventy-six year's there will no longer be a Pearson in charge of the statistics at the Department there which has become world famous. Egon Pearson was educated at Winchester and Trinity College, Cambridge, and continued his studies in statistics at University College, London, where he became a lecturer in 1921. Not long afterwards Jerzy Neyman joined the Department, and before long he and Egon Pearson began a remarkable series of papers which effectively laid the foundations of the NeymanPearson theory of statistical inferonce, undoubtedly one of the profoundest influences on modern statistical thought. Pearson has continued to work in this field and the related area of confidence-interval theory and has notably advanced knowledge of the sample range. His work on the Ordnance Board of the Ministry of Supply during the Second World War was recognized by his appointment as C.B.E. in 1946. $\mathrm{He}$ has also taken particular interest in the teaching of statisties; his work both at University College and as chairman of various committees of the Royal Statistical Society has laid both students and colleagues under a heavy burden of indebtedness to him for his constant endeavours to raise the standards of statistical instruction. $\mathrm{He}$ was president of the Royal Statistical Society during 1955-57 and received the Society's Gold Medal in 1955.

For about 25 years Pearson has been editor of Biometrika, and the high standing of that journal is largely due to his painstaking work and constant eare. Another of his many contributions has been his work on statistical vables, embodied in the Pearson-Hartley "Tables for Statisticians, Part 1", and the Biometrika series of reprints. His many friends will be glad to know that he intends to devote a good deal of his time to continuing this work.

Prof. M. S. Bartlett

Prof. Maurice Stevenson Bartlett, professor of mathematical statistics in the University of Manchester, is to succeed Prof. Pearson. Prof. Bartlett read mathematics at Queons' College, Cambridge, and was awarded the Rayleigh Prize in 1934. After a short period as essistant lecturer at University College, London, and four years as statistician with Imperial Chemical Industries, Ltd., he returned to Cambridge as a lecturer in statistics in 1938 . With the late John Wishart he helped to introduce modern statistical methods there and contributed some noteworthy research papers in a wide range of subjects: experimental design, factor analysis, regression theory and statistical inference. $\mathrm{He}$ was appointed to the chair of mathematical statistics at
Manchester in 1947, and has worked there since that time. His principal contributions in more recent years have lain in two main fields, multivariate analysis and stochastic processes including timeseries, both of them complicated and difficult subjects in which his work has given him a world-wide reputation.

\section{Communication Research at Keele :}

Prof. Donald M. MacKay

The University College of North Staffordshire, Keele, has appointed Dr. Donald M. MacKay to the new Granada researeh chair of communication, founded by a gift of Granada Television Network, as from June 1, 1960. Dr. MacKay, who is at present reader in physics at King's College, London, graduated from the University of St. Andrews in 1943. After war-time work on radar with the Admiralty, he joined the staff of King's College, where he was concerned with the early development of information theory and the theory of 'brain-like' self-organizing information systems. On the experimental side, a period of research on the informational limits of highspeed analogue computing led to his present interest in the mechanism by which information is processed in the central nervous system.

The work at the University College of North Staffordshire is expected to develop along three main lines: (1) the study of perceptual mechanisms, and the development of methods for the analysis of electrical brain-activity in perception ; (2) the development of artificial mechanisms capable of identifying patterns in space or in time, as an experimental 'testing ground', for theories of perception; (3) the study of disorders of function, as clues to the organiza. tion of the brain. Research on these interdisciplinary lines will require the collaboration of physiologists and experimental psychologists as well as of physicists and electronic engineers; and the setting up of an independent University department at Keele for the purpose marks a significant step in the academic development of this new subject. Dr. MacKay's gifts as a research worker and a teacher will be sorely missed at King's College ; but we may surely look forward to a period of great activity and development in his new environment. In spite of his new respons. ibilities, we may also be sure that his interest in undergraduates and their problems will continue undiminished.

Principalship of Fourah Bay College: Dr. D. Nicol

Dr. Davinson Nicol has been appointed principal of Fourah Bay College, the University College of Sierra Leone, in succession to Mr. J. J. Grant. Dr. Nicol was educated at primary schools in Nigeria, the Government Model School, Freetown, and the Prince of Wales School, Freetown. In 1943 he entered Christ's College, Cambridge, having won an open Colonial scholarship for medicine. He was elected Foundation Scholar at Christ's College in 1946 and also in that year was the Open Universities Entrance scholar to the London Hospital. In 1947 he obtained first-class honours in the Natural Sciences Tripos and he graduated in medicine at the London Hospital in 1950. Dr. Nicol was awarded a Beit Memorial Fellowship for Medical Research in 1954, and when he became a Fellow of Christ's College, Cambridge, in 1957, he was the first African to be elected to a fellowship at either Oxford or Cambridge. During 1952-54 he was lecturer in physiology and biochemistry in University College, Ibadan, 